\title{
THE PRACTICE OF FAMILY HEALTH STRATEGY WORKERS WHEN CARING FOR WOMEN IN GENDER VIOLENCE SITUATIONS
}

\author{
Vanda Palmarella Rodrigues ${ }^{1}$, Juliana Costa Machado², Aline Vieira Simões ${ }^{3}$, Vilara Maria Mesquita Mendes \\ Pires $^{4}$, Mirian Santos Paiva ${ }^{5}$, Normélia Maria Freire Diniz ${ }^{6}$
}

\footnotetext{
${ }^{1}$ M.Sc. in Collective Health. Assistant Professor, Department of Health, Universidade Estadual do Sudeste da Bahia (UESB). Jequié, Bahia, Brazil. E-mail: vprodrigues@uesb.edu.br

${ }^{2}$ M.Sc. in Nursing and Health. Assistant Professor, Department of Health, UESB. Jequié, Bahia, Brazil. E-mail: julicmachado@ hotmail.com

${ }^{3}$ M.Sc. in Health and Nursing. Assistant Professor, Department of Health, UESB. Jequié, Bahia, Brazil. E-mail: line.vieira@ hotmail.com

${ }^{4}$ M.Sc. in Collective Health. Assistant Professor, Department of Health, UESB. Jequié, Bahia, Brazil. E-mail: vilaragondim@ yahoo.com.br

${ }^{5}$ Ph.D. in Nursing. Associate Professor, School of Nursing, Universidade Federal da Bahia (UFBA). Salvador, Bahia, Brazil. E-mail: paivamirian@hotmail.com

${ }^{6}$ Ph.D. in Nursing. Adjunct Professor, School of Nursing, UFBA. Salvador, Bahia, Brazil. E-mail: normeliadiniz@gmail.com
}

\begin{abstract}
The aim of the present study was to describe the practice of Family Health Strategy workers when dealing with women in gender violence situations. It is a qualitative study, conducted with 25 healthcare workers from three Family Health Strategy units in a municipality of the state of Bahia, Brazil. Data were collected through a semi-structured interview and analyzed based on the discourse analysis method. The results yielded two empirical categories: expression of violence against women due to gender issues, with display of physical and psychological violence by a spouse, and strategies to face up gender violence. The second category displayed that the unit's actions that do not contemplate gender issues and that referrals to assistance services do not receive counter-referrals. We emphasize the need for Family Health Strategy staff to receive qualification for acting in gender violence situations, and for public management to promote a network structure for assistance services.
\end{abstract}

DESCRIPTORS: Violence against women. Family health. Gender and health. Nursing.

\section{PRÁTICA DE TRABALHADORA(E)S DE SAÚDE NA ATENÇÃO ÀS MULHERES EM SITUAÇÃO DE VIOLÊNCIA DE GÊNERO}

\begin{abstract}
RESUMO: Objetiva descrever a prática de trabalhadora(e)s de saúde da Estratégia de Saúde da Família às mulheres em situação de violência de gênero. Pesquisa de abordagem qualitativa, realizada com 25 trabalhadora(e)s de saúde de três unidades da Estratégia de Saúde da Família de um município baiano. Os dados foram coletados por meio de entrevista semiestruturada, e analisados com base na técnica de análise do discurso. Dos resultados emergiram duas categorias empíricas: expressão da violência contra a mulher decorrente de questões de gênero, evidenciando violência física e psicológica ocasionada pelo cônjuge e estratégias de enfrentamento mediante a violência de gênero, demonstrando que as ações não contemplam as questões de gênero e o encaminhamento/referência aos serviços assistenciais não recebem a contrarreferência. Ressaltamos a necessidade de qualificação das equipes da Estratégia de Saúde da Família para atuação nas situações de violência de gênero, e fomento pela gestão pública para a estruturação da rede de serviços assistenciais. DESCRITORES: Violência contra a mulher. Saúde da família. Gênero e saúde. Enfermagem.
\end{abstract}

\section{PRÁCTICA DE TRABAJADORES DE SALUD EN LA ATENCIÓN A MUJERES EN SITUACIÓN DE VIOLENCIA DE GÉNERO}

\begin{abstract}
RESUMEN: Objetiva describir la práctica de trabajadores de salud de la Estrategia de Salud de la Familia a mujeres en situación de violencia de género. Investigación cualitativa realizada con 25 trabajadores de salud de tres unidades de Estrategia de Salud de la Familia de una ciudad bahiana. Los datos fueron recolectados, analizados basándose en la técnica de análisis del discurso. De los resultados emergieron dos categorías empíricas: expresión de la violencia contra la mujer por cuestiones de género, evidenciando violencia física y psicológica ocasionada por el cónyuge y estrategias de enfrentamiento mediante la violencia de género, demostrando que las acciones no contemplan cuestiones de género y la referencia a los servicios asistenciales no reciben contrarreferencia. Resaltamos la necesidad de calificación de los equipos de Estrategia de Salud de la Familia para actuación en situaciones de violencia de género y promoción por la gestión pública de la estructuración de la red de servicios asistenciales.
\end{abstract}

DESCRIPTORES: Violencia contra la mujer. Salud de la familia. Género y salud. Enfermería. 


\section{INTRODUCTION}

In the global scenario, since 2002, the World Health Organization has emphasized that, although violence is not considered an issue for health care itself, it constitutes a severe public health problem for several reasons: causing injuries, physical and emotional trauma and even death. Violence is defined as the use of physical force or power, whether threatened or actual, against oneself, against another or against a group or community. It results or presents a high likelihood of resulting in suffering, psychological harm, maldevelopment or deprivation, or even death. ${ }^{1}$

The health sector classifies and ranks violence according to its empirical manifestation, such as that which is directed toward oneself, known as self-directed violence; interpersonal violence, which contemplates family and community violence, as well as collective violence, which includes a broader dimension, affecting a greater part of society. ${ }^{2}$

Bringing our attention to family violence, it can occur at different severity levels, by means of physical, sexual, and psychological abuse, neglect, abandonment, and maltreatment, among other manifestations. Its perpetrators can be people with family relations, be they spouses or relatives, or an intimate bond within a relationship based on power, be it physical, age, psychological, hierarchical and/or gender-related. ${ }^{3-4}$

In this context, domestic and family violence against women consists of any action or omission that leads to the woman's death, injury, moral or material damages, and physical, sexual or psychological suffering. It can take place within the domestic unit, i.e., in people's permanent cohabitation space, by those with or without family ties, including those who are sporadically part of the family; within the family, understood as a community formed by individuals who are or consider themselves relatives, united by natural ties or those of affinity or expressed will; and in any intimate affective relationship, in which the aggressor is involved with or has been involved with the woman in a violence situation, regardless of cohabitation status. ${ }^{5}$

Domestic violence began to gain visibility as a social and health problem in the second half of the $20^{\text {th }}$ century, in the late 1960s, when research began to be conducted about family relationships, women's traditional role in the family and the female condition in society. Thus, it became a politi- cal category for feminist demands, encompassing issues of gender, age, social class, race/ethnicity, religion and education. Women began to question their socially attributed roles, which for the most part were disqualifying, oppressive, lacking in status and responsible for restricting them to the domestic scope. This political organization started to demand equal rights for men and women, consolidating itself in the 1970s through the Women's Rights Movement. ${ }^{6}$

Despite these initiatives, we are still faced with a significant increase of women in situations of violence. This is a consequence of intimate relationships with aggressive partners, which are strongly influenced by cultural issues that permeate gender relationships. These define social roles for men and women, constituting the factors that lead to unequal relationships between men and women.

In this perspective, "gender inequality constitutes one of society's greatest contradictions, which has been maintained throughout the history of civilization and has placed women in a social position of subordination. In one of its extremes forms of manifestation, this inequality leads to violence against women, result of power asymmetry, which translates into relationships of force and domination. Generally speaking, gender violence has become a social phenomenon that greatly influences the way women live, become ill and die". 7:626

Socially constructed cultural issues constitute the foundation of gender violence and organize the social roles for each actor, how to be a man and or a woman, who attacks and who is attacked. These phenomena have come to be considered natural attitudes of social relations. ${ }^{8}$

A study conducted in 27 Brazilian municipalities, between the period of August 1, 2006 and July 21, 2007, indicated that the majority of domestic and sexual violence victims were female, ranging from children to older women. The study also indicated that adult women, aged between 20 and 59 years represented $79.9 \%$ of the victims of aggressions, which were generally committed by one single individual of the male gender. ${ }^{4}$

Violence against women affects the health not only of women, but also of the family as a whole, resulting in a series of implications in the process of psychosocial development. It also increases the burden on social and health services, requiring interventions based on intersectorality. ${ }^{9}$

The consequences of violence to the health- 
illness of women demand that healthcare workers act in a sensitive and effective manner with the women who seek out their care. Thus, dealing with violence must not focus solely on treating its consequences, but on primary prevention. In the current healthcare model, in which the family is placed in the center of care, health workers are in strategic positions that allow for the development of mechanisms that empower and heighten women's awareness. These mechanisms act to deconstruct the established inequality and reconstruct gender-equitable relationships. ${ }^{7}$

Experiencing the context of the Family Health Units, during supervision sessions of the Supervised Curricular Internship (ECS I, as per its acronym in Portuguese) for undergraduate students of the Universidade Estadual do Sudoeste da Bahia (UESB), we observed numerous situations of vulnerability and violence against women in the families registered in the program, within the region covered by the units where the internship took place. Furthermore, we identified the difficulty of health workers in dealing with family violence, due to lack of specific technical knowledge regarding the situation, as well as to other difficulties found in intersectoral articulation, conditions that are necessary for implementing intervention strategies.

We also wish to emphasize that the demands made by women in situations of violence to health services require that health workers take actions that take into account complexity of the phenomenon, in the perspective of comprehensive care. All of these factors made the authors take an interest in the theme and made us aware of the need for more widespread discussion of these workers' practice when dealing with violence against women, with an emphasis on gender.

It is our understanding that FHS teams need qualification in order to act in situations of violence. Their practice needs to be inserted into gender discussions, in the sense of empowering women to face up to violence. In order to accomplish this, forces must be joined with other health, social, legal, and police assistance services. Other social facilities, such as neighborhood associations, religious and women's groups must also be involved, due to the complex nature that permeates the context of violent acts.

We base the present study on the analytical category of gender. It is considered to be an integral element of social relations, based on the perceived differences between sexes; which are constituted primarily as a way of signifying the established power relationships between men and women, socially and culturally built in an unequal manner. ${ }^{10}$ The concept of gender leads to a better understanding of the elements that drive and perpetuate this inequality, based on a more critical conception of reality.

In this sense, the objective of the present study is to describe the practice of FHS workers when dealing with women in gender violence situations.

This study can contribute to changing the practices of healthcare workers when dealing with gender violence in the health service's daily routine. Health services can seek a new perspective and way of acting that attends to the needs inherent to the context of each woman in a violent situation. These actions must be based on compassionate listening, with the goal of empowering women so they can face up to violence with autonomy, safety and by exercising their citizenship, overcoming socially established gender inequalities. To this effect, the FHS must also base its interventions on articulated and intersectoral actions.

\section{METHODS}

This is a qualitative study conducted in three Family Health Units (FHU). One of these units had a double team, thus our study encompassed a total of four FHS teams in the municipality of Jequié, located in the state of Bahia, Brazil.

Twenty-five health workers from the FHU took part in this study, among which: four nurses, three nursing technicians and 18 Community Health Agents (CHA). All health workers were invited to participate, however, it is worth noting that the physicians did not display any interest in taking part.

Participants were selected according to the following inclusion criteria: 1) Health workers in the FHU in which the curricular internship ECS I, UESB, was carried out; 2) Health workers who were aware of facts and/or could identify women in situations of violence within the scope of the FHU.

Data were collected through semi-structured interviews, between October 2009 and June 2010, using a recorder. The interviews were based on two triggering questions: What types of violence against women are identified at the FHU? What actions are developed after identifying situations of violence against women? 
In order to abide by ethical guidelines, the study was analyzed and approved by the UESB research ethics committee, under protocol no. 055/2009. Participants read and signed the free and informed consent form, after any pertinent clarifications.

For data analysis, we used the method of discourse analysis, which studies the worldview of subjects as inscribed in their discourse; a socially determined view, which leads us to understand the production process which gave way to the discourse and to conduct a broader reflection about the conditions in which it was emitted. ${ }^{11}$

This technique allowed us to analyze each specific expression in depth, and the context in which it was created. We observed the reasons for each participant's satisfaction, dissatisfaction or implicit opinions by noticing the several ways subjects expressed themselves.

Throughout this process of data analysis, we identified the most abstract level of the text. First, the text was analyzed with the aim of finding concrete and abstract elements. Next, data were grouped according to significant elements. Then, the central themes were apprehended, which in our study consisted of two empirical categories: 1) expression of violence against women due to gender issues; 2) strategies to face up to gender violence situations.

Data analysis was based on the writings of authors who research violence against women, using gender as an analytical category.

Participants were identified throughout the text using numbers according to the order in which their interview was conducted, followed by their professional category. In other words, interview number 1 with a community health agent, reads (I1, CHA) and so on.

\section{RESULTS AND DISCUSSION}

Participants were aged between 25 and 59 years, and of these, only two were men. The data regarding schooling displayed that five had completed their undergraduate studies and 20 had completed high school. Time of service in the FHU varied from 1 to 13 years. In terms of religion, 13 participants were catholic, 11 evangelical and one was a spiritist.

Two categories emerged from the empirical data of the interviewees' discourse, as follows.

\section{Category 1 - Expression of violence against} women due to gender issues

The discourse inherent to this category portrays women as vulnerable to physical and psychological violence in the domestic environment, generally inflicted by a spouse due to jealousy or the use of alcohol or other drugs. This category demonstrates the domination of men with respect to women, causing social isolation.

Physical violence [...]. In my own field of work, I heard about this one case [...] where the husband [...], it was already customary for him to always hit her, beat her, and one of these days he even cut her hair off, which was very long, he cut half her hair off out of jealousy. [...] (I2, CHA).

[...] violence related, [...] to husband and wife, [...] another case was that of a couple, she was completely bruised, [...] but she didn't want to come here to the health unit (I12, CHA).

Through their discourse, participants indicated that violence against women is, in general, perpetrated by men in a dominant position, with the intent of aggression, and dishonoring the women's image. In this sense, we found two situations in which the woman was attacked physically, the first one due to jealousy and in the second, we noticed that the women chose not to bring visibility to her partner's violent acts.

In light of this, "the implications of marital violence for woman's health increase in magnitude, for through research, these acts of aggression cease to be invisible. The difficulty of visualizing the risks to women's health is due to many factors, such as, for example, the fact that violence happens in the private domain and is a reason for fear and shame that prevents the woman from bringing it to light" ${ }^{\prime 2: 28}$

Based on these discourses, we can also infer the influence of sexist ideology on the partner's behavior, who feels entitled to beat his partner. This denotes a gender issue permeated by men's superior position with respect to women, understood by society as a very natural fact. This makes it easier to tolerate violence within the private family context.

In this sense, gender constitutes a primary form of signifying power relationships, for it is an element inherent to social relations, based on the perceived differences among the sexes. ${ }^{10}$ This configuration is made very evident in situations of violence against women. 
In turn, beliefs about gender identities, which are ingrained in society as a whole, reflect the asymmetry of power between the couple and makes the domination of the man over his wife seem natural, as well as the social role she takes on when marrying, taking care of the home and children. This unequal gender construction favors the establishment of marital violence and allows us to comprehend situations in which some women remain in this relationship. ${ }^{13}$

Women frequently experience ambivalent relationships in terms of what they feel for their spouse and we believe that codependency is one possible interpretation that should be better investigated, especially in cases where expressions of love and hate coexist between the couple. ${ }^{14}$

The following excerpts display the occurrence of physical and psychological violence against the women by her spouse, due to jealousy and power abuse. These situations demonstrate that the woman allows herself to feel controlled by her partner, living in isolation, in such a way that the violent acts are restricted to the family domain.

Recently, in my region there is a family, [...] she even comes here to the unit for follow up, and the gate used to be all open, then now she closed it all up, or he did, [...] I asked: 'why did you close up the gate?' [...] she answered [...] 'my husband wanted to close it' [...] (19, CHA).

[...] I went to the house and he was assaulting the grandmother [mother-in-law] and wife. The wife had given birth fifteen days prior [...] and he greeted me as if nothing had happened, [...] he opened the door and the wife took the opportunity to go outside, but in that moment, she had been assaulted, with her baby in her arms, the grandmother had also been assaulted [...] (I25, CHA).

Through the informant's discourse, we can identify the presence of psychological violence against the woman, culminating in her social isolation. In general, psychological violence is used in the attempt of intimidating a woman and forcing her to live within a cycle of violence and threats, reaffirming the male hegemony in this relationship.

The answers of interviewee 25 show that, besides assaulting his partner, the aggressor also assaulted his mother-in-law, in line with the Brazilian Maria da Penha law which establishes that all it takes to define domestic and family violence against women is for people be intimately related, regardless of blood ties and cohabitation status. ${ }^{5}$ In our opinion, from the moment people co-exist in a domestic environment, a process of family involvement has begun, involving family values such as proximity, bonds and affection.

Another aspect to be considered regards the fact that marital violence may go unseen, restricted to the binomial man-aggressor and/or woman-victim. However, it goes unseen especially as a problem originating in the construction of male identities for men whose family relations were marked by the absence of dialogue and the presence of physical aggression, which can possibly lead to future violent intimate relationship. ${ }^{15}$ Furthermore, we believe that defining a woman as a victim reaffirms the position of inferiority and passiveness of women in social relations, annihilating her autonomy and the right to citizenship.

Another issue observed in the analyzed discourse refers to the use of alcohol and other drugs. This is a specific individual, family and collective condition that makes the family groups treated by the FHS workers more vulnerable to violence.

There is also another part of the region in which most of the violence is due to drug use, against women (I5, CHA).

[...] the husbands who drink, [...] the environment they live in [...] gives way to many psychological disorders, for they are oppressed, [the wife] she has to deal with the things her husband says and not say anything in order to avoid being physically assaulted [...] (I13, CHA).

It is important to emphasize that the use of alcohol and other drugs disorganizes the family and motivates aggressive acts in gender relationships, leading to the oppression of women.

Many times, violence between couples is unleashed by the man when he cannot accept the woman's interference in his alcohol-related habits or behaviors. In these cases, the partner can place the blame for the aggression on the woman. ${ }^{16}$

Based on the discourse of worker 13, we also emphasize that although cases of violence seem to be more easily identified when they result in visible injury, this worker was able to identify complaints of psychological and social nature. These are generally not so visible, and establishing the presence of psychological violence against women depends on the sensitivity of the health worker involved in the context.

\section{Category 2 - Strategies to face up to gender violence}

The discourse of the participants regarding this category indicated that, when faced with situ- 
ations of violence against women, they rely on other members of the FHS staff in order to create strategies to face up to the problem.

In general, we take the case to our Friday afternoon meetings with the entire staff, especially to our coordinator. She is informed about the case, and she helps us find help in the bodies responsible for each situation [...] then she gives us [...] feedback on all the work that was done (I1, CHA).

[...] we inform the coordinator [...]. Unfortunately, there are many family cases that go unresolved [...] we can't always solve them because it's out of our scope [...], many cases of aggression, of violence against women, [...] do not find the support [services of other sectors which assist women in situations of violence], [...] effectiveness [...] (I25, CHA).

Based on these excerpts, we found that FHS workers attempt to discuss cases of violence and define their strategies as a team. However, in some situations, these workers feel they lack the conditions to solve the problem. Solutions do not depend solely on the team's actions, and they do not find the necessary support in other sectors that assist women in situations of violence. This displays the frailty of intersectoral articulation when facing up to gender violence.

In this context, we notice that when situations of violence against women are identified, it is of utmost importance that FHS workers not work in isolation, but involve other staff members, considering the inherent consequences of violent contexts. Furthermore, each situation requires a specific reaction and must be analyzed in all its aspects: emotional, socioeconomic, cultural, religious, among others. Workers should avoid judgments or making decisions without the will or consent of the women in situation of violence. To this effect, FHS staff workers must bring to light gender issues and take human rights and citizenship into account.

Nonetheless, we did not find in the workers' discourse the idea that facing up to gender violence requires the woman's participation, in the attempt to encourage a proactive attitude and the exercise of her citizenship. Intervention seems to be limited to team discussions about what actions to take.

In the context of primary health care, comprehensive care must prevail. First, because violence needs to be treated in all its complexity, taking into account health promotion, prevention and case management, from the treatment of its consequences to facing up to the problem through interdisciplinarity, with multiprofessional and intersectoral care. Second, because the woman must be considered as the central point of any decision making and she must participate in such decisions regarding her care. ${ }^{17}$

The National Humanization Policy of the Brazilian Unified Health System defines providing sensitive and embracing care as one of the most relevant guidelines. In the context of health care, this guideline requires that the professional attend to every person who seeks out health services, listen to their requests, adopt a caring attitude and respond to their health needs. In other words, it consists of providing care in such a way as to solve and take responsibility for the issue, providing the person or family with guidance regarding other healthcare services, when needed, in order for assistance to be continued. The healthcare professional must establish articulated actions with such services, in order to guarantee the effectiveness of referrals. ${ }^{18}$

The participants' discourse portrays the team's integration as a favorable aspect for developing intervention strategies for solving cases of violence.

[...] the team always helps one another, regardless of being a nurse, an aide or even the community agents themselves [...] (I3, CHA).

$[. .$.$] the integration of the team, [...] the agents$ come and report the problem, coordination tries to solve it, $[. .$.$] when people come here they do not leave without$ a solution [...] (I4, Nursing technician).

[...] The support that we find here in the team, when we encounter a situation like this, we report it in our meetings, [...] everybody gives their opinion [...] (I7, CHA).

As expressed in the informants' discourse, when the team provides the necessary support to its members, facing up to the situation becomes in fact easier and more effective.

Thus, facing up to violence must be a collective and not isolated effort. Collective actions lead to a more widespread impact and avoid interventions focused only on each particular case, causing an impact on the existing reality.

The participants' answers also indicate that FHS workers identify, counsel and refer women in situations of violence to assistance services that act to prevent and combat violence.

Identifying, counseling and referring to the competent body [...] (I8, Nurse)

I talk with and encourage her to seek out help at the woman's police station [...] (I11, Nursing technician). 
Referral to the [...] social worker and the support of the family health unit (I14, Nurse).

The discourse mentions the practice of referrals, such as to the specialized Woman's Police Station and to social assistance. We emphasize that such referrals are necessary, however, the initial priority should be listening and dialogue, so that the woman has the chance to express all the implications inherent to her context of violence and so that the decision to seek out another body for assistance is a conscious one, based on information made available by the FHS team. Thus, the woman in situation of violence can become aware of the nuances of gender issues influencing such violent acts, as well as of the need for her to exercise her citizenship.

It is our understanding that this referral must be made after exhausting all of the team's possibility for action. This prevents situations in which health workers delegate actions to other services only because they need to rid themselves of the problem.

A study ${ }^{19}$ found that the clinical practice of health professionals does not consist of providing caring and sensitive attention to the needs of women in violent situations. Clinical actions consist of referrals and do not always result in an adequate solution for these women's demands. In this study, discourse also revealed a practice that does not provide women with orientation encouraging the construction of gender equality and of their autonomy. Practices were greatly technicist, oriented by protocol that devalue, in the case of gender violence, the professional's role in constructing critical awareness in women so that they can face up to the situation.

In this sense, we emphasize the need for workers who assist women in situations of violence to bring more visibility to gender issues. They must modify their practice in order to care for the inherent demands of each woman's life context, contemplating the human and social dimensions. The woman must also be empowered so that, together, they decide which actions better fit each unique and singular experience, motivating the exercise of her citizenship.

The inadequate attitudes of professionals who attend to women in situations of violence can reproduce prejudice and sexist positions that permeate social relationships between the sexes. Furthermore, they can perpetuate the inequalities between men and women, reinforcing the emotional experience of vulnerability in the assaulted women. This creates a vicious cycle between interpersonal and institutional violence that prevents services from fulfilling their vocations of interrupting the chain of violence production. ${ }^{20}$

In relation to nursing, whose object of work is caring, it needs to be re-dimensioned, in order to constitute a professional practice that seeks comprehensiveness, basing its actions on reflections on the reality in context and inserting the woman as a proactive subject in the construction of her care.

Another relevant factor presented by the FHS workers' discourse refers to the difficult access to, as well as the lack of support from and effectiveness of the bodies that are part of the service network that prevent and combat gender violence.

[...] access to the other bodies which could help us re-structure this family becomes a little more distant for each of us [...] (I1, CHA).

[...] the omission and lack of feedback [...], we do our job and then we have no feedback, that's the difficulty, and it's even discouraging (I3, CHA).

[...] the places we should seek out do not give us support, which would be, in this case, the health secretariat, social assistance, and we do not find support (I9, CHA).

Participants gave special emphasis to the lack of feedback from other assistance bodies regarding the turn of events for the case's resolution. This absence of feedback makes it challenging to carry out comprehensive and articulated care, which is necessary for favorable outcomes that satisfactorily contemplate the specificities of each situation.

In this sense, it is necessary for counterreferrals to be made within the network of gender violence, so that the woman can be re-referred to another assistance service, such as the Woman's Police Station, social assistance and legal services and her needs be attended to. This should take place together with the completion of standardized forms that would establish a permanent dialogue between the professionals responsible for that woman's care. These forms should provide a detailed description of the care provided, as well orientation and suggestions for the next steps to be taken.

Article 9 of Law Maria da Penha establishes that women in a situation of domestic and family violence must receive articulated assistance according to the principles and guidelines set forth by the Social Assistance Organic Law, the Unified Health System, the Unified Public Security System, among other norms. It must also contemplate 
public policies for protection and emergency care, when necessary. ${ }^{5}$

With regards to assistance, we highlight that it is necessary to integrate the actions of professionals from different assistance sectors. Violence requires health actions in order to treat and prevent physical and emotional harm, as well as the risks to sexual and reproductive health; legal orientation regarding property rights and situations which constitute crimes; police assistance for reporting crimes, filing complaints, protection in situations of vulnerability, removing the aggressor from home; shelter in risk of death situations for the woman and/or her children; social services with orientation about benefits that can help her have better living conditions and/ or that contribute to facing up to violence, and psychosocial services, in order to elaborate the violent family situation and the construction of new life projects and patterns of intimate relationships. ${ }^{21}$

Thus, the health sector must not act on its own regarding gender violence and must seek to establish networked actions, as well as establishing partnerships with social equipment within the FHSjurisdiction, such as non-governmental organizations, neighborhood associations, churches, among others, so that together they can face up to the phenomenon of violence, since it presents structural causes inherent to socioeconomic, cultural, political and health aspects.

Qualified assistance requires that the health professional consider the woman's subjectivity, allowing for a space for non-judgmental listening. Therefore, professionals need to develop the sensitivity required for identifying violence as a health risk and acting in conjunction with others, for this phenomenon extrapolates the health sector, making network articulation a necessity. ${ }^{9}$

In this sense, health workers, among them nurses, and other bodies and institutions that are part of the care network that deals with violence, must be prepared to provide orientation and support to women in situations of violence. These professionals should take them in and support them in their decisions after the aggression, as well as implement actions of prevention and those that empower women so they can become the protagonists of their own stories.

\section{CONCLUSION}

This study allowed us to understand a broader aspect of violence regarding gender issues, which greatly influence relationships established between men and women in our society. Based on our results, health workers in the context of the FHS encounter situations of violence against women displayed by physical and psychological aggression inherent to gender relations.

Regarding the intervention strategies implemented by the FHS workers in situations of violence against women, we emphasize the health team's participation through orientation, counseling and referrals to assistance services, following a standardized process that makes it difficult to approach gender issues when caring for women in situations of violence.

The fact that the women are cared for at the FHU, where several different professional categories are present, means that these workers must be aware of the situations of violence experienced by women in several different contexts of health care. They must seek out the support network and redirect their actions in order to provide these women with comprehensive health care, giving them a voice, helping to empower them. Professionals should also help them to understand how important it is that they be responsible for the decisions regarding their care, based on a critical awareness about gender issues.

In light of these considerations, we also emphasize the need for providing women who decide to report their aggression with all the protection and assistance as provided by law. This requires that public management restructure the services of its care network, so as to guarantee that she can have access to and be cared for by qualified professionals in the different healthcare, education, social and legal assistance services, sensitive to the issue of gender violence. They must be capable of implementing the necessary actions for attending to the women's needs, as well as inciting her to exercise her citizenship. This means avoiding prescriptive attitudes as well as those that reproduce the "naturalization" of violence.

\section{REFERENCES}

1. Organização Mundial de Saúde. Relatório mundial sobre violência e saúde. Genebra (CH): OMS; 2002.

2. Minayo MCS. Violência e saúde. Rio de Janeiro (RJ): Fiocruz; 2010.

3. Ministério da Saúde (BR), Secretaria de Políticas de Saúde. Violência intrafamiliar: orientações para a prática em serviço. Brasília (DF): MS; 2002.

4. Ministério da Saúde (BR), Secretaria de Gestão Estratégica e Participativa. Temático prevenção de violência e cultura de paz. Brasília (DF): OPAS; 2008. 
5. Brasil. Lei n. 11.340, de 7 de agosto de 2006. Cria mecanismos para coibir a violência doméstica e familiar contra a mulher. Diário Oficial da República Federativa do Brasil, 8 Mai 2006. Seção 1.

6. Gomes NP, Diniz NMF, Araújo AJS, Coelho TMF. Compreendendo a violência doméstica a partir das categorias gênero e geração. Acta Paul Enferm. 2007 Out-Dez; 20(4):504-8.

7. Guedes RN, Silva ATMC, Fonseca RMGS. A violência de gênero e o processo saúde-doença das mulheres. Esc Anna Nery Rev Enferm. 2009 Jul-Set; 13(3):625-31.

8. Vieira LB, Padoin SMM, Souza IEO, Paula CC, Terra MG. Típico da ação das mulheres que denunciam o vivido da violência: contribuições para a enfermagem. Rev Enferm UERJ. 2011 Jul-Set; 19(3):410-4.

9. Gomes NP, Bomfim ANA, Diniz NMF, Souza SS, Couto TM. Percepção dos profissionais da rede de serviços sobre o enfrentamento da violência contra a mulher. Rev Enferm UERJ. 2012 Abr-Jun; 20(2):173-8.

10. Scott J. Gênero: uma categoria útil para a análise histórica. $2^{\mathrm{a}}$ ed. Recife (PE): SOS Corpo; 1995.

11. Fiorin JL. Linguagem e ideologia. $6^{\mathrm{a}}$ ed. São Paulo (SP): Ática; 2003.

12. Monteiro CFS, Souza IEO. Vivência da violência conjugal: fatos do cotidiano. Texto Contexto Enferm. 2007 Jan-Mar; 16(1):26-31.

13. Gomes NP, Diniz NMF, Camargo CL, Silva MP. Homens e mulheres em vivência de violência conjugal: características socioeconômicas. Rev Gaúcha Enferm. 2012 Jun; 33(2):109-16.
14. Pazo CG, Aguiar AC. Sentidos da violência conjugal: análise do banco de dados de um serviço telefônico anônimo. Physis. 2012 Jan-Abr; 22(1):253-73.

15. Gomes NP, Freire NM. Vivência de violência familiar: homens que violentam suas companheiras. Rev Bras Enferm. 2005 Mar-Abr; 58(2):176-9.

16. Deeke LP, Boing AF, Oliveira WF, Coelho EBS. A dinâmica da violência doméstica: uma análise a partir dos discursos da mulher agredida e de seu parceiro. Saude Soc. 2009 Abr-Jun; 18(2):248-58.

17. D'Oliveira AFPL, Schraiber LB, Hanada H, Durand J. Atenção integral à saúde de mulheres em situação de violência de gênero: uma alternativa para a atenção primária em saúde. Ciênc Saúde Colet. 2009 [acesso 2013 Mai 10]. 14(4): [online]. Disponível em: http://www.scielo.br/scielo.php?script=sci_ arttext\&pid=S1413-81232009000400011\&lng=pt

18. Ministério da Saúde (BR), Secretaria de Atenção à Saúde. Núcleo Técnico da Política Nacional de Humanização. Acolhimento nas práticas de produção de saúde. Brasília (DF): MS; 2010.

19. Santi LN, Nakano MAS, Lettiere A. Percepção de mulheres em situação de violência sobre o suporte e apoio recebido em seu contexto social. Texto Contexto Enferm. 2010 Jul-Set; 19(3):417-24.

20. Villela WV, Vianna LAC, Lima LFP, Sala DCP, Vieira $\mathrm{TF}$, Vieira ML, et al. Ambiguidades e contradições no atendimento de mulheres que sofrem violência. Saúde Soc. 2011 Jan-Mar; 20(1):113-23.

21. Hanada H, D'oliveira AFPL, Schraiber LB. Os psicólogos na rede de assistência a mulheres em situação de violência. Rev Estud Fem. 2010 Jan-Abr; 18(1):33-60. 